\title{
THE REAL AND EXPECTED PRIVILEGES OF THE SECURITY SERVICE COLLABORATORS RECRUITED FROM ACADEMIC MILIEU IN THE 1980s
}

Despite the elaborated techniques of electronic surveillance, personal sources of information still remain the best possible method of infiltrating a criminal milieu. Such methods gain special importance in totalitarian states. Collaborating with the Security Service almost always had some notable benefits. For some of the TWs, collaborating was an additional, sometimes quite substantial, source of income. One of repeating motives for collaboration was a will to improve one's professional position or to easily obtain a permission to go abroad. There were also persons, who were impressed with having contacts with the Security Service functionaries. Almost all collaborators were using different forms of help from the part of the Security Service. Most of them would obtain real financial and material profits. The spectrum of favours offered to those helping the repressive state apparatus was very extensive.

Keywords: Security Service, personal source of information, privileges, financial remuneration, other rewards

doi:10.1515/sho-2015-0005

\section{PRELIMINARY REMARKS}

Despite the elaborated techniques of electronic surveillance, personal sources of information still remain the best possible method of infiltrating a criminal milieu. Such methods gain special importance in totalitarian states where the governments endeavour to control the whole society, which implies that there is a need to build networks of informants in all milieu. This was the case in Poland and in other countries, which fell under communist regime after World War II. Looking from the modern-day perspective one might get the impression that creating a system of omnipresent surveillance was one of the main goals of the Polish Communist 
Party (PZPR) and of the Ministry of the Internal Affairs which handled its implementation.

The most valuable type of a personal source of information (OZI) was a secret collaborator (TW), and his connections with political police had a formalised character. In most cases a TW would sign a collaboration obligation. Often he would be remunerated financially or given in-kind benefits. Secret collaborators would personally choose pseudonyms, but in rare cases pseudonyms would be given by the Security Service (SB) functionaries. Until 1960 there were three categories of TW - agent, informant and resident. The agent was the most valuable category of a collaborator, as it was the agent's task to actively infiltrate his milieu. The informant was basically responsible for watching persons from his circles, whereas the resident's aim was to create his own network of informants. Since 1960 these three categories were substituted by one - secret collaborator (TW). This category functioned until the end of the Polish People's Republic (PRL). In the same time, a new category of personal source of information was created - civil support. ${ }^{1}$

Categories of the Security Service's (SB) collaborators who were active in the 1970s and 1980s were defined in the Instructions Regarding Operations of the Security Service Subordinate to Ministry of Internal Affairs, which was an appendix to Resolution no. 006/70 Issued by the Minister of Internal Affairs on February 1, 1970, Regarding Operations of the Security Service Subordinate to the Ministry of Internal Affairs. ${ }^{2}$ The resolution was signed by the Internal Affairs Minister of the day, Kazimierz Świtała. According to the Instructions, the category of a Secret Collaborator, formally introduced in 1960, was sustained, whereas two new categories of collaborators were created in the same time - service contact (KS) and operational contact $(\mathrm{KO})$. The latter two substituted the category of civil support (sometimes called also civil contact or discrete contact). There was also

${ }^{1}$ Ruzikowski Tadeusz, Agenci [Agents], Biuletyn Instytutu Pamięci Narodowej, no. 3/2005, p. 36-48.

${ }^{2}$ Instrukcja o pracy operacyjnej Stużby Bezpieczeństwa resortu spraw wewnętrznych. Zatacznik do Zarzadzenia nr 006/70 ministra spraw wewnętrznych z dnia 1 lutego 1970 r. w sprawie pracy operacyjnej Stużby Bezpieczeństwa resortu spraw wewnętrznych [Instruction on the operations of the Security Service of the Ministry of Internal Affairs. Attachment to Ordinance no. 006/70 of the Ministry of Internal Affairs of February 1, 1970 on the operations of the Security Service of the Ministry of Internal Affairs] [in:] Ruzikowski Tadeusz [ed.], Instrukcje pracy operacyjnej aparatu bezpieczeństwa (1945-1989) [Instruction on the operations of Security Service (1945-1989)], Warszawa 2004, p. 121-139. 
a new category prepared for persons to be called consultants. ${ }^{3}$ The number of secret collaborators varied significantly throughout the period of functioning of Polish People's Republic. In 1988 the number of secret collaborators in the network reached almost $100,000(98,000)$. The size of the agents' net had never been as large before - not even during the period of Stalin's rule, when at its peak in 1953 the number of operations department's collaborators reached 85,000 . On the other hand side, the statistics show that the lowest number of active collaborators functioned in 1960 - only 8,720 persons in the whole country. Surveillance of a wide spectrum of polish society was the responsibility of the Department III of the Security Service. The size of the agents networks in different milieu depended directly on the level of danger the milieu posed. In 1976 Department III maintained the highest number of secret collaborators in industrial production facilities (over 3.4 thousand secret collaborators, which constituted about $40 \%$ of all secret collaborators of the Department III). Academic Institutions, and especially higher education institutions, were the second largest area of surveillance (over 1 thousand secret collaborators, 12\%), and agriculture was monitored by almost 700 TWs $(8 \%) .{ }^{4}$

The circumstances and the recruitment method used to acquire a new informant were of crucial importance to further cooperation. This is the reason why Security Service officers had to pay the most careful attention to the "acquirement" talk. Usually they would collect any possible information regarding a potential candidate with all due diligence before such a talk would be organised. The candidate's position in his milieu was carefully analysed, especially his potential for performing operations at the time being and in a longer perspective. The Instructions Regarding Operations of the Security Service... allowed the recruitment to be executed on the following basis:

[...] compromising materials, if one can suspect that the fear of their publication might incline the candidate to agree to collaborate, on special occasions, proofs of criminal activity, pursuit of obtaining personal benefits. In some special cases, justified by operational activity, it was allowed to deliberately create circumstances favourable to recruitment. The Instructions also pointed to a possibility of recruiting persons "who

${ }^{3}$ Wokót teczek bezpieki - zagadnienia metodologiczno-źródłowe [Around special service files - methodological and resource issues], Musiał Filip [ed.], Kraków 2006, p. 46-50; Osobowe źródta informacji - zagadnienia metodologiczno-źródłoznawcze [Personal sources of information - methodological and resource issues], Musiał Filip [ed.], Kraków 2008.

${ }^{4}$ Ruzikowski Tadeusz, Agenci... [Agents...], p. 43, 47. 
would agree to become a collaborator because of internal sense of shared civic responsibility for safety and public order. ${ }^{5}$

In September 1983 the Director of SB Department III-1 in Krakow, major MA Wiesław Hryniewicz, underlining the need to develop the network of OZI at Jagiellonian University (UJ), described the methods of acquiring new collaborators in the following way:

The actions aiming at the development of the network of TW in the spaces and milieu under surveillance of the Department III-1 shall be executed through:

- pointing the current sources at acquiring information about persons from their surroundings who might have the prerequisites that would justify an attempt of acquiring them

- conducting talks with persons going abroad and maintaining contacts with foreigners

- using compromising materials obtained from police units

- analysing thoroughly the information sent from the "W" Department and $\mathrm{Bu}-$ reau $^{6}$

- using information obtained from KOs and KSs regarding conflicts and inaccuracies in their work and research areas

- analysing and using preliminary materials gathered in the so called desk files. ${ }^{7}$

Among the TWs recruited by Department III of Provincial Bureau of Internal Affairs (WUSW) in Krakow in 1980s, the largest group was formed by persons who decided to collaborate on the basis of "shared civic responsibility". The concept defined:

[...] a pursuit to actively stand against the existing inaccuracies; ideological and political convictions and psychological and emotional factors. ${ }^{8}$

The analysis of individual cases shows that this was a very vast concept and did not necessarily had much in common with loyalty to PRL. Often it explained opportunism, procrastination, but also human fear of the security forces and subconscious fear about the sake of one's family. Sometimes agents would be recruited on the basis of compromising materials, however much more frequently they would agree to cooperate with the Security

${ }^{5}$ Instrukcja o pracy operacyjnej Stużby Bezpieczeństwa... [Instruction on the operations of the Security Service...], p. 127-128.

${ }^{6}$ Correspondence control.

${ }^{7}$ Archive of the Institute of National Remembrance in Kraków (AIPN Kr) 056/96, p. 85-86.

${ }^{8}$ Franaszek Piotr, "Jagiellończyk". Działania Stużby Bezpieczeństwa wobec Uniwersytetu Jagiellońskiego w latach osiemdziesiatych XX w. ["Jagiellonczyk". Security Service operations towards the Jagiellonian University in the 1980s.], Kraków 2012, p. 62-68. 
Service out of the fear of disciplinary or legal responsibility. Sometimes such anxieties were justified, however usually they were the result of pure human fear. ${ }^{9}$ In most cases it was the fear of the consequences of causing an accident or driving under the influence of alcohol. There were some exceptions of more serious offences like taking part in a fight or stealing. ${ }^{10}$

\section{PRIVILEGES}

Collaborating with the Security Service almost always had some notable benefits and - in many aspects - brought privileged position in one's milieu. For some of the TWs, collaborating was an additional, sometimes quite substantial, source of income. One of repeating motives for collaboration was a will to improve one's professional position or to easily obtain a permission to go abroad. There were also persons, who were impressed with having contacts with the Security Service functionaries. They felt satisfaction and - in their own view - superiority to the persons from their milieu. Almost all collaborators were using different forms of help from the part of the Security Service. Most of them would obtain real financial and material profits. Whereas a relatively small group of OZI was not remunerated in any tangible way. The spectrum of favours offered to those helping the repressive state apparatus was very extensive. Possible benefits and advantages in obtaining a privileged position that were accessible to persons collaborating with the Security Service are presented below, with regard to the network of agents functioning at the Jagiellonian University. ${ }^{11}$

\section{Financial remuneration}

According to regulations imposed by the Instructions Regarding Operations..., a secret collaborator should be reimbursed for all the ex-

\footnotetext{
${ }^{9}$ AIPN Kr 056/108, vol. 2, p. 82.

${ }^{10}$ Franaszek Piotr, "Jagiellończyk"... ["Jagiellonczyk"...], p. $62-68$.

${ }^{11}$ Franaszek Piotr, Agentura Stużby Bezpieczeństwa na Uniwersytecie Jagiellońskim w latach osiemdziesiatych [Security Service intelligence at the Jagiellonian University in the 1980s] [in:] Franaszek Piotr [ed.], Naukowcy władzy, władza naukowcom [Scientists for authority, authority for scientists], Warszawa 2010, p. 120-140.
} 
penses incurred when executing a given mission. When a Security Service officer met with the collaborator in a restaurant or a café he would take the bill. The agent was also to be reimbursed for all books and other materials printed without the consent of censorship that he had purchased and brought to the Security Service. But the additional remuneration obtained was an important aspect of the activity of the agents' network. The Instructions Regarding Operations of the Security Service... underlined the need to reward the TWs:

[...] appropriately reward the achievements, diligence and initiative (a pecuniary or inkind reward, assistance in difficult situations), keeping in mind that the prize should never become a factor inclining to unrealistic or subjective informing. ${ }^{12}$

The basic form of compensation was financial, paid in cash. It was an effective method of binding an OZI to the Security Service. According to some preserved accounts, the money would be paid to secret collaborators as long as until the end of 1989 and even in 1990.

The analysis of the materials in the archives points to a close correlation between the sums of money collected and the level of activity and usefulness of a secret collaborator. A TW could be offered disproportionally large amounts of money given his level of commitment only in the beginning, immediately after he had been recruited. There are even documented cases of paying the agent already during the first meeting. It was a form of a bait. In practice an agent would be accounted and remunerated for having performed a certain task. Taking active part in operations executed by the Security Service was the best-paid option, and such actions included taking over polygraphic materials and apparatus or already printed leaflets, or running destructive activities in clandestine oppositional organisations and groups. Providing information that was already widespread resulted in significantly lower remuneration. Such common-knowledge information did not have much value to the SB operations. Repeatedly, the leading officer would refuse to pay anything, in this way "punishing" his agent for not fulfilling the task he was assigned properly.

The collaborator would prepare the bill confirming the receipt of the money in handwriting and he would sign it with his pseudonym. This is the reason why in the work files of the TWs there are so many sheets and scraps of paper that were torn down from notebooks and notepads, often

12 Instrukcja o pracy operacyjnej Stużby Bezpieczeństwa ... [Instruction on the operational work of the Security Service...], p. 130. 
crumpled and with irregular fringes - they all served as money receipts. The officer would present them at the cash-desk of the Security Service. Money spent on such purposes would be listed in the balance sheets of the Operational Fund of SB Department III. According to $\$ 1$ from the Resolution of the Minister of Internal Affairs issued on December 29, 1969:

The operational fund [...] serves to cover the expenses, in national and foreign currencies, associated with the operational requirements of the Security Service and the Police Service, and especially the expenses incurred during the organisation of an inflow of information enabling or rendering it easier to prevent, identify, fight criminal activity, provided that such expenses cannot be financed within the disclosed budget because they need to be kept secret. ${ }^{13}$

The use of this fund was under strict control and any attempts of embezzlement undertaken by the functionaries met with very severe penalties, including immediate, disciplinary dismissal from the service. Quarterly statements of the operational fund include the amount of sums spent by certain functionaries of the SB on the maintenance of the contact venues and conspiratorial flats, sums spent on gifts for the secret collaborators and the costs of consumption spent by the functionaries during meetings in gastronomical venues. To a certain extent such information allows us currently to identify the moment of first-appearance of a given informant and to at least partially reconstruct the frequency of meetings between given collaborators and their leading SB officers. However, it should be kept in mind that the most valued collaborators were invited to the conspiratorial flats and contact venues, not to cafés or restaurants. And this is the reason why in their cases in the books of the Operational Fund there are no data about the number and costs of such meetings. ${ }^{14}$

The accounts between SB functionaries and their informants registered in the Operational fund book allow to establish the amount of remuneration paid to the secret collaborators. The TW pseudonyms and sometimes their car registration numbers were provided in the accounts. As the pseudonyms were sometimes repeated, the latter information is of crucial im-

${ }^{13}$ AIPN Kr 065/23, vol. 5, p. 43.

14 Skubisz Pawel, Casus Barana - rzecz o defraudacji funduszu operacyjnego SB [The "Baran" case - about Security Service operational fund misappropriation], Aparat Represji w Polsce Ludowej 1944-1989, no. 1(5)/2007, p. 296-315; Skubisz Paweł, Fatszerstwa dokumentacji operacyjnej popetnione przez funkcjonariuszy Urzędu Bezpieczeństwa i Stużby Bezpieczeństwa [Operational file forgeries commited by Security Office and Security Service officers], Dzieje Najnowsze, no. 42/4, 2010, p. 49-74. 
portance, as it also allows to unequivocally identify the collaborators who obtained financial remuneration during meetings with the functionaries. Cash reports show the amounts spent on the consumption, the gifts, and most of all on additional remuneration paid during meetings with secret collaborators, service contacts and operational contacts.

It is extremely difficult to give a summary amount of the remuneration each informant was paid throughout the whole period of cooperation. Any established amount should be only considered as the minimal amount each personal source of information was given, as the preserved sources are not complete and some documents are missing. It is definitely very important and revealing to see the exemplary sets of remunerations paid to certain collaborators in different periods and to compare these amounts to the level of salaries and prices of these times.

The SB functionaries would quickly discover the need to provide additional "remuneration" to the secret collaborators. All the officers leading TW "Wiśniewski" would underline his vital interest in obtaining material benefits:

He is cunning - rather greedy. As a person who has seen the work in counter-intelligence he is aware, probably not accurately, that refusal might have a negative impact onto his further plans. He is probably counting on some kind of material or other benefit that the cooperation might bring him". ${ }^{15}$ The officer who closed the cooperation with TW "Wiśniewski" in 1981 wrote similarly: "Despite the high social position [a professor of law at the UJ, renowned in international academic circles, PF] he was eager to accept even small amounts of remuneration. ${ }^{16}$

From the very beginning, the benefits he would be offered, were quite high. On the application form that was presented for formal acceptance of the newly-recruited TW the Director of SB Department III in Krakow wrote a note in hand-writing that said that there shall be sums of more than 500 PLN, and in the middle of 1960s this meant substantial resources.

Unlike "Wiśniewski", TW "Krakus" was rarely given any remuneration for his activity. In his description prepared in January 1976 by Lieut. Ryszard Buczek for the Director of Department III, it was stated that throughout the whole period of cooperation he was given 2,000 PLN and two cognacs. Only once later, in March 1979, was he gratified with again the same amount. ${ }^{17}$

\footnotetext{
15 AIPN Kr 009/9167, p. 26.

16 Ibidem, p. 15.

17 AIPN Kr 00100/1285/D (mf).
} 
Since the beginning of cooperation in 1968, TW "Las", and subsequently TW "Antoni" would be paid a relatively high remuneration. Until December 1969 he was altogether given 10,000 PLN. In the following year his leading functionary, captain Stanisław Knapik, claimed that he should be remunerated with no less than 2,000 PLN on a quarterly basis, arguing that he was a valuable collaborator. As a result, within first 7 years of cooperation he received over 27,000 PLN. ${ }^{18}$

Remuneration that the secret collaborators were paid in 1980s is relatively well-documented. However, the amount of information provided is not exhaustive, it rather illustrates the scale of financing the persons cooperating with the SB and the size of the overall costs incurred on the maintenance of a network of OZIs. It must not be forgotten that especially in the second half of the 1980s, the rate of inflation was at very high levels and therefore the nominal amounts varied in their real value during the analysed decade. As an example, the amounts of remuneration paid to some of relatively well-paid SB Department III collaborators who were engaged in the infiltration of the Jagiellonian University are presented below (Table 1). As was already mentioned, some of the secret collaborators would receive some payments even until 1990.

Table 1. Exemplary amounts of remuneration paid to secret collaborators of the SB Department III in Krakow in the 1980s (in thousand PLN)

\begin{tabular}{|c|c|c|c|c|c|c|c|c|c|c|}
\hline TW Year & 1980 & 1981 & 1982 & 1983 & 1984 & 1985 & 1986 & 1987 & 1988 & 1989 \\
\hline Marco & 34 & 35 & 35 & 26 & 25 & 48 & 31 & 50 & 35 & 120.5 \\
\hline Alex/Bart & 13 & 32.5 & 17 & 28 & 13 & 15.5 & 35 & 17 & 29 & 10 \\
\hline Tomek/Zbyszek & 26.7 & 22.6 & 21.15 & 17.1 & 2 & 4 & 55 & 105.2 & 152.4 & 50 \\
\hline Herbert & & 2.5 & 13 & 17 & 9 & 13 & 82 & 135 & 105 & 45 \\
\hline Monika & 5 & 3.3 & 17 & 10 & & 10 & & & & \\
\hline
\end{tabular}

Source: AIPN Kr 041/83, vol. 5, p. 13-21, 59-66, 101-107, 150-158, 216-222, 260-266, 302-305, $345-$ 349; vol. 7, p. 11-15, 54-59, 97-101, 147-151, 206-210, 254-259, 302-305, 352-358; vol. 9, p. 14-17, 150-151, 222-225; vol. 12, p. 18-22; vol. 13, p. 17-22; vol. 14, p. 13-16; vol. 15, p. 20-27; AIPN Kr 041/85, vol. 1, p. 15-20, 74-79; vol. 2, p. 15-18, 83-90; AIPN Kr 041/93, vol. 1, p. 22-27; vol. 4, p. 17-21, 86-91; AIPN Kr 041/94, vol. 1, p. 18-22, 89-93; vol. 2, p. 15-17, 91-95, AIPN Kr 041/97, vol. 2, p. 15-18, 84-87, 150151, 212-214.

18 AIPN Kr 009/9063, vol. 1, p. 18-36. 


\section{Other material and intangible rewards}

The SB functionaries would show the proofs of their "gratitude" also in other forms. The collaborators would be offered gifts. Usually those gifts would be flowers, more expensive alcohols (a bottle of cognac, whisky, brandy), sometimes a pack of coffee, chocolate, juice, tinned ham or stockings. In the period of persisting economic hardship every gift was precious. One of the employees of the Jagiellonian University Law Faculty, in documents presented as a service contact "Aleksander", during a meeting in November 1965 was given a ream of paper for his typewriter to rewrite his Ph.D. thesis, and as is known, in those days there was a deficit of typewriter paper. ${ }^{19}$ Such occasions as Name Day, Women's Day and important personal events would never be missed. In May 1968 the leading officer gave a bunch of flowers to TW "Mag" on the occasion of passing an oral exam qualifying for the position of an assistant-professor. In his note, the functionary wrote: "TW was very touched and grateful to our Service for having remembered about her private matters" ${ }^{20}$ She expressed similar emotions when the SB functionaries paid her visits in the hospital and in sanitarium, showing care about the state of her health.

Then again, Lieut. Zbigniew Cioś in the spring of 1982 paid a fine of 300 PLN imposed on TW using pseudonym "Adler". In August 1983 Second Lieut. Tadeusz Walkowicz granted his operational contact "RJ" a bottle of cognac worth 1,180 PLN as a reward for his help in "operationally securing the Summer School of Polish Culture and Language". ${ }^{21}$

TW "Wiśniewski", two years before he was formally recruited, made an interesting offer to the SB functionaries. At the end of their meeting he asked the officers responsible for his recruitment to: "organise him the installation of a fixed telephone line in his private apartment as he has a social telephone which is causing him problems". ${ }^{22}$ In those days a telephone, especially in big cities, was a luxurious element of flat furnishing. The functionaries were well aware that by helping him out this way they would strongly bind this agent to the security forces.

When the researchers were concerned, the "prize" for collaboration would mean help in obtaining a scholarship abroad and assistance during

\footnotetext{
19 AIPN Kr 009/6735, p. 76.

20 AIPN Kr 009/9227, vol. 1, p. 19, 51.

${ }^{21}$ AIPN Kr 009/9888, p. 8.

22 AIPN Kr 009/9167, vol. 1, p. 35.
} 
such scholarship period, or in obtaining a position at a foreign university (e.g. as a lecturer of polish as a foreign language) or a position of a representative to some international organisation. Considering the rate of exchange of foreign currencies to PLN, almost every journey abroad meant a considerable increase in one's income. The collaborators were given help in taking additional positions or in acquiring a well-paid temporary sidejob, e.g. as a language teacher at KW PZPR in Krakow. Others would ask for help in being allotted an apartment or ask to discontinue administrative or penal proceedings held against them. As far as it was possible, and at the same time pursuing their own aims, the SB functionaries would grant such help. Repeatedly it would happen that such declared help was fake and the proceedings continued according to regular administrative rules. Then again there were other OZIs who would count on the support of SB in expelling from UJ persons who were a nuisance to them. The functionaries would pay visits to their "subordinates" during their stays in hospitals and sometimes they would even participate in the funerals of "their" collaborators.

An intervention made by an SB functionary was once very successful when an agent using pseudonym "Grzegorz" was called to the Road Traffic Department, because of a traffic offence he had committed. He was supposed to take an obligatory control exam. Thanks to the support of the SB the offence was cancelled. ${ }^{23}$ Probably an even more substantial help was given to this collaborator by the SB functionaries in the beginning of 1981. In the following characteristics describing TW "Grzegorz" there is a recurring phrase: "One of the flaws discovered during the cooperation is the Agent's inclination to foreign currency turnover". It was this activity that brought him to custody suite on Montelupi street in Krakow in January 1981. He was released after 12 days. The SB was also aware of the fact that he was storing stolen paintings. ${ }^{24}$

Regardless of the above-mentioned financial "rewards", TW "Las" ("Antoni"), counted mostly on other privileges and other forms of help. It can be best seen in the final talk, during which the secret collaborator broke up the cooperation. As he was avoiding contacts with the SB officers in the beginning of May 1982 he was called to the quarters of SB Department III in Krakow. Captain Knapik, who recorded the talk, wrote:

\footnotetext{
${ }^{23}$ AIPN Kr 009/10039, vol. 3, p. 147.

24 Ibidem, p. 183.
} 
He came in very nervous, requested explanation as to the reason of the summons, he would answer in a very formal, "official" way. Although we have been on first name terms with each other for 16 years he would call me "Sir" and demanded that the talk be recorded..$^{25}$ When asked about further cooperation [...] he replied: "For many years I have actively and within my possibilities helped the SB, but despite this I was persecuted at the Jagiellonian University, my academic promotion was being blocked and so on - I reported it after you had left the SB - to your colleagues, but none of them did anything to help me. Currently I suffer from neurosis, I am ill and additionally I have different kinds of family problems, and I have not given up on my strive to become assistant-professor and I still encounter problems with that. [...] I cannot afford it any more. I cannot see my further cooperation with the SB. I need to start treating my health, I need to do research, I need to support my family somehow. Please, take this into consideration. ${ }^{26}$

His whole speech was filled with grief towards the SB for not having helped him be promoted to an assistant-professor. His first work presented as the basis for the promotion was dismissed in 1979. The collaborator therefore started preparing a new book, hoping strongly on the support of the Ministry of Internal Affairs organs. Unfortunately, this support was not granted. Knapik was fully understanding of "Antoni"'s explanation. He expressed great gratitude for his past, long-lasting cooperation. There are no doubts that Knapik's gratitude was sincere. He appreciated "Antoni"'s contribution to "protecting" the University. He considered him one of the best collaborators he managed to recruit and in his way Knapik felt sorry for "Antoni". This is why he wrote in the "Operational notes":

I think that TW "Antoni" until 1973 and even later until around 1979, was one of the most valuable ones in this Department. The information he provided was trustworthy, very accurate, prepared expertly so that it would be very useful for operational purposes. I think that either the period of cooperation was too long or some of the SB functionaries made mistakes that I do not know of in their contacts with TW, or maybe it was the repeating failures in his academic career - these might be the motives of such a deep nervous breakdown of the TW which resulted in his retreat from collaboration. I also think that our moral duty is - when only it is possible - to give TW support by SB functionaries in operational way so that he will be helped to overcome the obstacles he encountered on his way to academic promotion. ${ }^{27}$

SB supported their agents in their strives to obtain lucrative contracts abroad, at the same time using this support for their own operational purposes. An example of such actions was the case of TW “Adam”, who collab-

\footnotetext{
${ }^{25}$ AIPN Kr 009/9063, vol. 7, p. 225.

${ }^{26}$ Ibidem, vol. 1, p. 225-225v, p. 41-42.

27 Ibidem, vol. 7, p. 225v.
} 
orated with the SB since the break of 1970s and 1980s. He was mentioned in a correspondence between organisational units of the Security Service in the middle of 1986, in relation to his plans of going to Vienna university as a polish literature lecturer. In the beginning of May the Director of SB Department III-1 in Krakow informed:

During his stay in Vienna TW "Adam" stayed mostly in the Institute of Slavic Languages of the local university. He was assured by the Director's office that they would apply to the local Ministry of Science and Research to repeat the call for a polish literature lecturer considering the application of TW. The initiative seems quite realistic if only it is met with a similar strive undertaken by our Ministry of Science, Higher Education and Technique to appoint such a position in terms of Polish-Austrian agreement on academic and cultural cooperation. TW "Adam" asked whether he could, in such a situation, count on our support, referring to his stay in Vienna in 1979-1982 when he rendered services to Dep. I of the Ministry of Internal Affairs. ${ }^{28}$

On the other hand side the Head of SB Inspectorate I informed Department I of the Ministry of Internal Affairs:

TW "Adam", asked by major J.[ohn] Krawczyk, who was handling him, declared being ready to execute operational tasks during his stay abroad and to remain in contact with our officer in Austria or FRG, just like it happened during his previous stay in Austria. Back then he maintained contact with comrade L. Pintera. He remained in contact also for some time after he had returned to the country. Back then he was using the pseudonym "Midro". Basing on the opinion of both major J. Krawczyk and com. L. Pintera I suggest to operationally use TW “Adam"'s stay for intelligence purposes of your Department, and therefore I suggest to consider a proper preparation for him before he leaves and to overtake him as a contact abroad. However, in this case it would be very important to exercise some operational actions by Department I of the Ministry of Internal Affairs in the Ministry of Higher Schooling and Technique to make sure that the possibility of appointing TW "Adam" was not cancelled by someone else being promoted to this position as a results of the so-called "fraternal connections". 29

Also other collaborator, using pseudonyms "Philosopher" and "Olgierd" would use help in organising his travels abroad. Registered in 1967 he was a valuable collaborator, which can be proven by the fact that in march 1971: "He received a passport with the right to cross the border multiple times, within and outside of Europe, until revocation". ${ }^{30}$ In the light of the passport policy of the day it was an exceptional situation and

\footnotetext{
${ }^{28}$ AIPN Kr 065/24, vol. 6, p. 180.

${ }^{29}$ Ibidem, p. 176.

30 AIPN Kr 309/399, p. 2v.
} 
a proof of a very deep trust on the side of the Ministry. As a collaborator of the SB Department III - 1 he was handled by, among others, the Director of the Department, which also showed the high rank assigned to him in the hierarchy of the collaborators. SB showed him gratitude also in other forms - both in cash (e.g. in the amount of 7,100 PLN in September 1988 and 6,690 PLN in December 1989) as in flowers worth e.g. 820 PLN in November 1988 and as much as 3,720 PLN in December of that year and 1,970 PLN in June 1989.

TW "Mag" had an exceptional motivation to undertake collaboration with the SB, counting on specific profits and privileges. Deputy Director of SB Department II in Krakow, major Jerzy Barcik thought that the motivation derived from "a need to take the anger out". ${ }^{31}$ But the analysis of the materials produced by TW "Mag" clearly shows that the main driving force of her actions was a feeling of strong antipathy against prof. Przemysław Mroczkowski, director of the English Literature Institute. "Mag" expected that with the help of the SB it would be possible to "put the relations in the Institute in order". Lack of appropriate actions on the SB side resulted, in the beginning of 1980s, in a serious frustration of the agent and lead to closing the cooperation of one of the most dedicated secret collaborators. This situation was described by Lieut. A.[ndrzej] Buluk:

TW resented us also. He did not state it directly, but one could figure it out. TW used to inform us about the persons allegedly morally unfit and professionally unprepared to act as academic lecturers. It did not bring the results he had wished for. On the contrary he had noticed that those persons, thanks to acquaintances and the support of the director - antagonist of the TW, were being promoted and remunerated. It caused TW to have doubts about he sense of maintaining further contacts and influenced the decision to put an end to the cooperation. ${ }^{32}$

It was with difficulty that the functionary convinced the agent to meet for the last time, which eventually took place on May 2, 1980 in Park Jordana. During this meeting he pointed again to Mroczkowski as the person who had been persecuting him in the Institute, blocking his voyages abroad and ordering him to perform duties which did not require the qualifications of a professor. In the opinion of the collaborator, there were many faults and inaccuracies in the Institute. He expressed grief as despite longlasting and devoted collaboration he did not get any help from the side of the SB. Turning to the lieutenant he was supposed to have said: "no

\footnotetext{
31 AIPN Kr 009/9227, vol. 1, p. 17.

32 Ibidem, p. 52.
} 
one needs me anymore and you don't need me anymore. What can I tell you?". ${ }^{33}$ In this case the functionaries did not fulfil the expectations of a secret collaborator.

\section{CLOSING REMARKS}

Despite strong connections with the PRL's special forces the SB collaborators not always could count on the help of their supervisors and it would also happen sometimes that they would become victims of the Service's actions. In one of the more interesting events described by $\mathrm{KO}$ " $\mathrm{RJ}$ " there was some information about an intervention in the students dormitory "Piast" in Krakow, in July 1984 performed by unknown persons claiming to be SB functionaries. Participants of the Jagiellonian University Summer and Polish School that "RJ" was taking care of, were lodged there. Again, in August 1985 the SB functionaries intervened in the Central Train Station in Krakow, when the participants of the Summer School of Polish Culture and Language, during their trip to Gdansk, photographed railway infrastructure objects. In the report, $\mathrm{KO}$ "RJ" underlined that the form of the intervention was an unpleasant surprise to everyone. In a memo, an SB functionary wrote:

Participants of the course, citizens of USA, were clearly satisfied that they finally met with the security service that they had heard of from hostile editors. They asked us questions, like whether the tour leaders would come back to the Summer School, if they would be beaten, how long they were going to be kept in the custody suite and so on. The situation was additionally inflamed by the fact that the whole group was being kept in a bus at the Station. In the opinion of the employees of the School this form of intervention brings bigger losses - mostly with respect to propaganda - than potential gains. In their opinion cases of similar incidents can and should be handled much more discretely, so that the participants of the course do not have the image of Poland as a police state. ${ }^{34}$

"RJ" also had an extremely bad luck when he was coming back to Poland by train in December 1984. Back then the functionaries of the Customs Office in Zgorzelec confiscated him five books printed in 1983

\footnotetext{
33 Ibidem, vol. 3, p. 350.

${ }^{34}$ AIPN Kr 009/9888, p. 24-24v.
} 
and 1984 in West Germany. The officer from the Border Inspection Post who recorded a note wrote:

While depositing the above mentioned books the citizen [...] was very outraged and crossed, he said that if they keep his books it would be a political scandal. He works at the Jagiellonian University. ${ }^{35}$

Many a time the functionaries would assure their "subordinates" of the help they were allegedly exercising, whereas in the reality all the matters were settled in an official way. This was the case with TW "Grzegorz", recruited in the beginning of 1980 for "offences committed in Hungary", for which, according to his leading officer, inspector Zbigniew Cioś, he might have been persecuted. In 1980 "Grzegorz" wanted to go on holidays to Bulgaria. During his stay in Hungary the record in his identity card, entitling him to travel within the communist countries, was cancelled by the local authorities. The collaborator turned for help to inspector Cioś. He in turn found out that the Passport Department did not impose any restrictions on "Grzegorz" regarding People's republics and that he could easily obtain a new record if only he had applied for it. But "Grzegorz" did not know about it. Cioś faked help writing:

Considering the engagement that TW "Grzegorz" has shown in the past I suggest that we should enable him to go to Bulgaria for his even better work in the following year and during the pilgrimage to Częstochowa. ${ }^{36}$

It was similar when "Grzegorz" decided to take up studies again in September 1981. He was allowed to start studies again according to the official rules, without an SB intervention. But also in this case Cioś wrote: "TW is convinced that we helped him in being admitted to studies". ${ }^{37}$

Piotr Franaszek PhD, full professor of History at the Institute of History of the Jagiellonian University in Kraków, Head of the Economic and Social History Chair at the Jagiellonian University. Scientific interests: social and economic history of the 19th and 20th century, activities of communist secret service during years of Polish People's Republic. Selected books include: Myśl techniczna w galicyjskim wiertnictwie naftowym w latach 1860-1918, Kraków 1991; Produkcja roślinna w Galicji doby autonomicznej, Kraków 1995; Zdrowie publiczne w Galicji w dobie autonomii, Kraków 2002; "Jagiellończyk". Działania Stużby Bezpieczeństwa wobec Uniwersytetu Jagiellońskiego w latach osiemdziesiątych XX w., Kraków 2012.

\footnotetext{
35 Ibidem, p. 19.

${ }^{36}$ AIPN Kr 009/10039, vol. 3, p. 153, 181.

${ }^{37}$ Ibidem.
} 